\title{
Ensuring future regeneration success of Qualea grandiflora Mart. (Vochysiaceae) in neotropical savanna (cerrado) biomes by reviewing the available information and identifying research gaps
}

\author{
Giovanna Da Ponte, \\ Franka Huth, \\ Sven Wagner
}

$\square$ Institute of Silviculture and Forest Protection, Department of Forest Sciences, Faculty of Environmental Sciences, TU Dresden, P.O. Box 1117, 01735 Tharandt (Germany)

\section{@ Giovanna Da Ponte}

(giovannadaponte@hotmail.com)

Received: Nov 14, 2017 - Accepted: Feb 12 2020

Citation: Da Ponte G, Huth F, Wagner S (2020). Ensuring future regeneration success of Qualea grandiflora Mart. (Vochysiaceae) in neotropical savanna (cerrado) biomes by reviewing the available information and identifying research gaps. iForest 13: 154164. - doi: 10.3832/ifor2684-013 [online 2020-05-02]

Communicated by: Paola Mairota

Qualea grandiflora Mart. (Vochysiaceae) is one of the most widespread species within the cerrado formation, which counts amongst the most threatened ecosystems worldwide. Understanding the regeneration ecology of $Q$. grandiflora is a central requirement for the success of conservation measures and silvicultural management strategies. Exhaustive investigation was carried out into each of the development stages, and the connected processes within the regeneration cycle, to provide a better understanding of the main factors influencing the regeneration ecology and the recruitment dynamics of the species. For this purpose, we analysed 92 different sources of information in this review, divided into two groups $(n=41$ with "basic species information" and $\mathrm{n}=\mathbf{5 1}$ with "specific information about regeneration stages and processes") relevant for regeneration and silviculture. Our literature review showed the high proportion of studies addressing the processes flowering, pollination and fruiting, whereas the subsequent processes like seed dispersal, seed storage, germination and seedling development are almost entirely lacking. This also applies for spatial information about environmental conditions and the related regeneration processes in $Q$. grandiflora. This knowledge is important for management, for example, knowledge of the critical distances between flowering and seed producing trees to ensure genetically diverse regeneration and the identification of safe sites for seedling establishment. Most of the practical suggestions in relation to increasing densities or growth of $Q$. grandiflora seedlings and saplings made in the literature are linked to less intensive fire management strategies adopted at certain times. The use of selective herbivory to reduce the increasing competition pressure exerted by invasive grasses and hampering $Q$. grandiflora seedlings is also cited. In this study we highlight the need for more complex species-specific information following the development stages and processes of the regeneration cycle so as to prepare a continuous strategy with a range of management approaches.

Keywords: Cerrado Formations, Environmental Influences, Regeneration Cycle, Silvicultural Management Strategies

\section{Introduction}

Qualea grandiflora Mart. is a typical tree species of the cerrado (neotropical savanna), a highly-threatened biome and one of the 25 "hotspots" of biodiversity worldwide (Myers 2000). The cerrado encompasses different vegetation types, and is technically termed cerrado sensu lato (Fig. 1).

The cerrado is one of the largest biomes in Brazil, with parts situated in Paraguay and Bolivia (Simon et al. 2009 - Fig. S1 in Supplementary material). In the year 2004, cerrado biomes covered approximately 2 million $\mathrm{km}^{2}$, mostly in the central region of Brazil (Eiten 1972). Studies have estimated that between $40 \%$ to $55 \%$ of cerrado formations have been cleared and that a high degree of fragmentation has occurred (Oliveira \& Marquis 2002, Jepson et al. 2010). Around $44 \%$ of the flora is endemic to this biome, and the total species richness is very high (Jepson et al. 2010), as well as the risk of extinction of cerrado species
(Siqueira \& Peterson 2003). The corresponding climate is seasonally tropical with a dry winter. Maximum monthly temperatures can reach $40^{\circ} \mathrm{C}$. The minimum values are close to $0{ }^{\circ} \mathrm{C}$ during May, June and July. Frost events are also common in the cerrado. The annual precipitation lies between $1200 \mathrm{~mm}$ and $1800 \mathrm{~mm}$ and is concentrated in spring and summer (October to March), which make up a rainy season with warm temperatures (Rawitscher 1948, Eiten 1972). Between May and September the levels of precipitation are greatly reduced and the mean temperatures fall (Klein 2000). The long dry periods are characterised by the limited availability of soil nutrients and frequent burning, caused mainly by man (Hoffmann \& Franco 2003). Therefore, the environmental conditions in the cerrado can be classified as stressful, and especially difficult for tree regeneration.

Q. grandiflora attains high frequencies, reaching proportions of up to $85 \%$ on the 


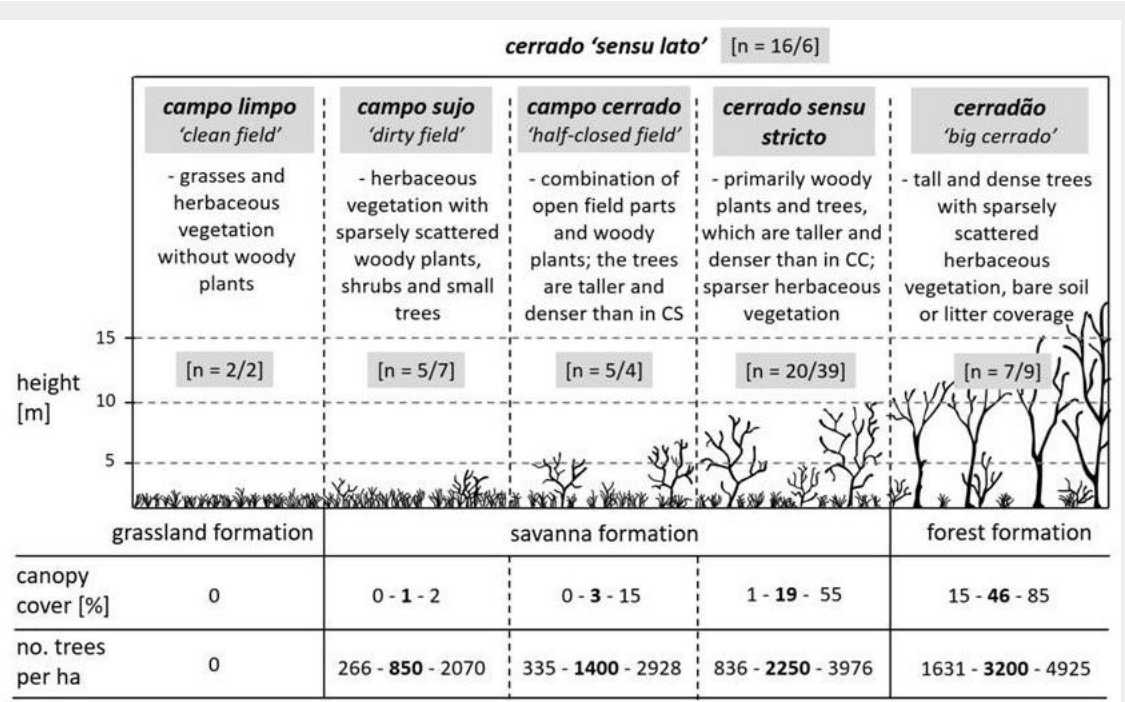

Fig. 1 - Overview of the cerrado sensu lato vegetation types according to Eiten (1972) and Ruggiero et al. (2002). Depending on the environmental characteristics, a series of vegetation types occurs in the cerrado sensu lato (CSL) savanna formation, henceforth referred to simply as cerrado, ranging from open grasslands (campo limpo, $\mathrm{CL}$ ) to dense woodlands (cerradão, CD), with three intermediate vegetation types. These three intermediate vegetation types are: campo sujo (CS), described as grassland with a scattering of shrubs and small trees; campo cerrado (CC), where there are more shrubs and trees but still a large proportion of grassland; and cerrado sensu stricto (CSS), where trees and shrubs dominate but with a fair amount of herbaceous vegetation (Oliveira \& Marquis 2002). Meanings of the numbers in the grey boxes: first number - publications including general information about Q. grandiflora, Vochysiaceae, cerrado, savannas or about the regeneration of other tree species typical of the cerrado biome; second number - publications specifically concerning the regeneration phases of Q. grandiflora or Qualea spp. investigated in this study, or the proportion of Q. grandiflora in the different formations; multiple responses possible.

376 analysed cerrado sites in Brazil (Ratter et al. 2003 - Fig. 2a, Fig. 2b). Its presence decreases from the cerradão (dense woodland) to the campo sujo (Eiten 1972). It is restricted to Central and South America, occurring in rain forests and in the cerrado (Litt \& Stevenson 2003, Carmo-Oliveira \& De Morretes 2009, Negrelle 2011). The tree species Q. grandiflora is a deciduous and anemochorous species (Mantovani \& Martins 1993). It is usually found from $700 \mathrm{~m}$ to $1100 \mathrm{~m}$ a.s.l., on dry and well drained sites occupied by dense woodlands and savanna formations (Costa \& Santos 2011, Negrelle 2011).

Q. grandiflora is a light-demanding, selec- tive xerophytic tree species classified as a pioneer tree species due to its occurrence in the early stages of succession on dry and poor soils. Adult trees reach heights of between $7 \mathrm{~m}$ to $12 \mathrm{~m}$, and $30 \mathrm{~m}$ to $40 \mathrm{~cm}$ in diameter. The tree traits of Q. grandiflora (e.g., thick, rough and irregularly fissured bark - Lorenzi 2002) are typical of species adapted to fire as the main disturbance factor occurring in their ecosystem (Bond \& Keeley 2005). Apart from its ecological importance, the wood of Q. grandiflora is used locally, for example, as timber, charcoal and firewood (Stafleu 1953, Protásio et al. 2014). The species is also important for the restoration of degraded areas and as an ornamental tree along roadsides and in urban areas due to its conspicuous flowers and fruits (Dousseau et al. 2013, Potascheff et al. 2019). Medicinal substances are extracted from the bark for use as antiseptics for the treatment of external wounds and for their anti-ulcerogenic properties (Gaspi et al. 2006, Hiruma-Lima et al. 2006), and also from leaf extracts, which have analgesic effects and can potentially act as an anti-convulsion medicine (Gaspi et al. 2006). Although Q. grandiflora is considered to be one of the most widespread and variably used tree species in the cerrado (Eiten 1972, Costa \& Santos 2011), there exists no strategy for the silvicultural or landscape-oriented management of this tree species (Ribeiro et al. 2013). This means in particular that there is no strategy with regard to its regeneration. The current lack of knowledge concerning the species' regeneration ecology poses difficulties in developing conservation strategies with practical relevance for the species. For all forest ecosystems worldwide, it is accepted that an understanding of the species-specific regeneration ecology is important to guaranteeing the continued presence of tree species as an important part of the vegetation community (Khurana \& Singh 2001, Leck et al. 2008). Fundamental information on different processes occurring within the regeneration cycle is necessary in order to develop species-specific conservation strategies (Bhadouria et al. 2016). The success of seedling establishment, in general, depends strongly on environmental factors during the different development stages. This is all the more obvious for tree species regenerated under harsh environmental conditions such as those found in the cerrado formations (Ferri 1961). Factors such as seed predation, fire, water stress and a low availability of nutrients may have an existential effect on the regeneration capacity of Q. grandiflora (Hoffmann 2000). It is important to identify the main bottlenecks in the regeneration cycle of Q. grandiflora, and to analyse whether and how they can be influenced or buffered by specific silvicultural measures (Martinez-Ramos et al. 2016).

We approached the problem through the following steps: (i) we analysed the current
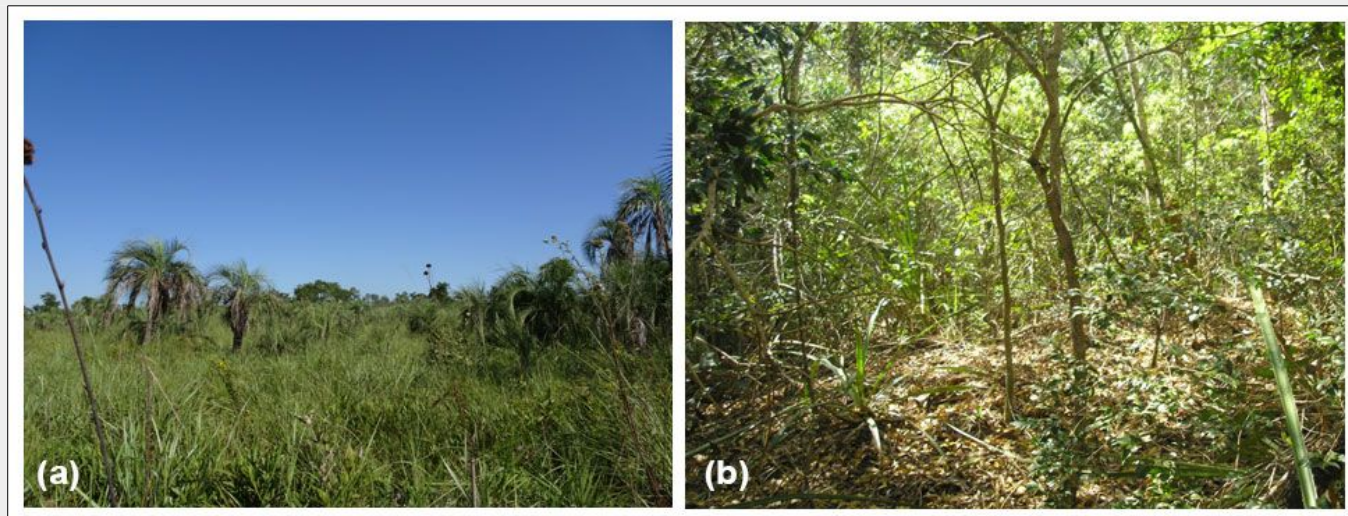

Fig. 2 - Pictures of structures typical of (a) the open cerrado formations and (b) the cerradão where Q. grandiflora is one of the most common tree species. 
knowledge of the development stages and specific processes linked to the regeneration cycle of Q. grandiflora by means of an extensive literature review; (ii) we identified the main factors influencing regeneration; (iii) we formulated possible protection and silvicultural measures for all regeneration stages; and finally (iv) we highlighted the most important gaps in the knowledge with relevance for future research. One of the main objectives behind the study was to use the information that emerged from the literature review to identify the gaps in the information that still exist in relation to the regeneration cycle of Q. grandiflora and to formulate questions for future research. The overarching purpose of this study was to scrutinise current management strategies and to suggest new management approaches that should be considered to achieve the in situ conservation of $Q$. grandiflora within the cerrado biome.

\section{Methods}

For the purpose of the literature review, the following literature databases were searched: Web of Science, Digital Book Information System (DBIS), CAB Abstracts, BIOSIS Previews, Google Scholar, the Catalogue of the Saxony State and University Library in Dresden (SLUB) and the Journal Storage Database (JSTOR). The search was undertaken for publications in the languages English, Portuguese and Spanish. Publication media such as scientific books, international peer-reviewed scientific articles, conference papers, reports and theses were integrated into the search. "Grey literature" was also included because unfortunately many relevant facts concerning the species were not to be found in the peer-reviewed publications. The choice of keywords was based on terms typically directly linked with the main development stages and processes in the regeneration cycles (Leck et al. 2008) of tree species. This common approach facilitated a systematic analysis and provided for better comparability with regeneration studies carried out for other tree species. For the literature search the name of the target species, Q. grandiflora, or of the associated family, Vochysiaceae, was combined with the main regeneration processes (flowering, pollination, fruiting, seed dispersal, seed storage, germination, growth of seedlings and saplings) and stages (flowers, pollen, fruits, seeds, germinants, seedlings, saplings - for detailed information see Tab. S1 in Supplementary material). Additional terms were used to define and describe the corresponding environmental conditions such as savanna formations, microsites, biotic and abiotic factors. A total of 108 publications related to the cerrado biome and to the Vochysiaceae family was filtered as a first step of the analysis (Fig. 3). After an initial review 16 publications were directly rejected for insufficient information content. The remaining 92 publica-

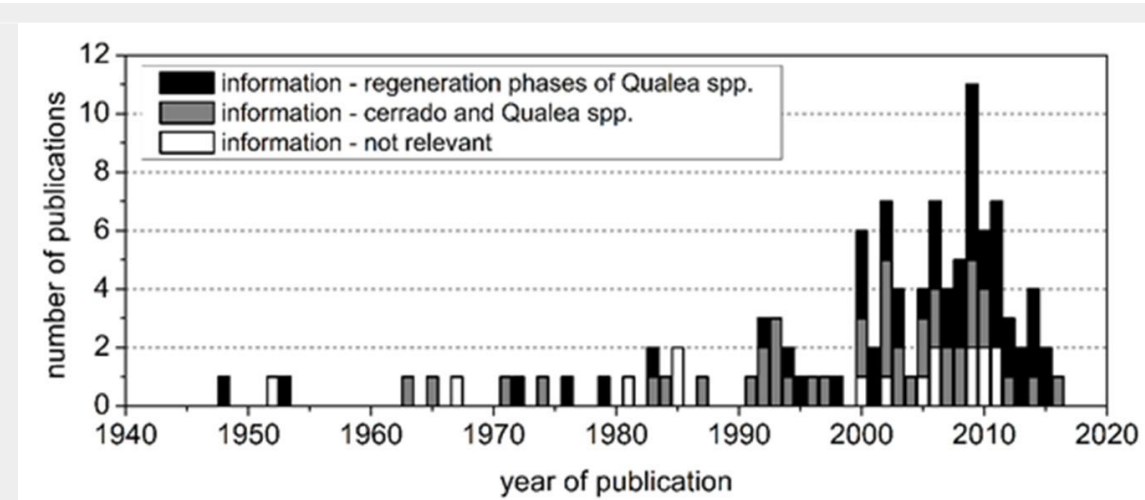

Fig. 3 - Publications $(n=108)$ presenting information on dry forests, cerrado formations and the tree species Q. grandiflora in the period 1948 to 2016. (white): publications excluded from further analysis for a lack of relevance to the topic $(n=16)$; (grey): publications of general relevance to the topic of the cerrado biome and the regeneration of tree species $(n=41)$; (black): publications of specific importance for the regeneration cycle of Q. grandiflora or Qualea spp. $(n=51)$.

tions were subjected to a more intensive review.

\section{Results}

Sixty of the 92 relevant publications were written in English, 31 in Portuguese and only 1 in Spanish. Distinguished on the basis of publication media, relevant information was found in journals $(n=79)$, books and monographs $(n=4)$, theses $(n=4)$, conference papers $(n=3)$ and grey literature $(n=2)$. Most publications $(n=64)$ were published in the period 2000 to 2016.

Based on the 92 publications, a first group of 41 publications was separated containing basic information connected with cerrado formations and Q. grandiflora. Publications in this group primarily contained information about Q. grandiflora as part of plant communities of different savanna formations and the climatic and soil conditions (Fig. 1). The second group of 51 publications directly addressed different aspects of the regeneration cycle of $Q$. grandiflora. This second group of studies was used for the following main data analyses. The contents of the second group of publications were distributed unequally between the different stages and processes in the regeneration cycle of Q. grandiflora. A high proportion of these used only descriptive methods (Oliveira \& Moreira 1992, Zaidan \& (arreira 2008). Fig. 3 shows the three different categories of relevance of the publications (1: lack of relevance; 2 : general relevance; 3: high relevance) relative to the regeneration aspects of Qualea spp. generally and Q. grandiflora specifically.

Almost all of the studies of the cerrado formations relevant for this review, and containing location coordinates, were carried out in Brazil (Fig. S2 in Supplementary material). This underlines the importance of the cerrado formation in Brazil, with coverage of approximately $25 \%$ of the territory (Miranda et al. 1993). Of those studies identified as being relevant for regenera- tion, 6 were related to unspecified cerrado sensu lato vegetation, characterised by the presence of Qualea spp. (Fig. 1). Most of the publications $(n=39)$ were related to the cerrado sensu stricto formation. A low proportion of the published studies concerned study sites in the cerradão $(n=9)$. As is shown in Fig. 4, the investigations into the Q. grandiflora regeneration cycle concentrated on physiological aspects of flowering $(n=19)$ and fruiting $(n=22)$.

Aspects of seed morphology, and corresponding seed dispersal mechanisms, were described and analysed in 12 and 18 publications, respectively. Information concerning seed storage was scarce. Studies examining the germination process $(n=13)$ and seedling development $(n=13)$ mostly focused on phenological details (Fig. 4). Of the relevant studies, 12 were entirely descriptive with no additional information on measurements. In 16 publications individual aspects with practical relevance for silvicultural management were presented, but no study was directly related to an overall species-specific regeneration management strategy or practical measures such as those presented for tropical tree species by Martinez-Ramos et al. (2016).

\section{Flowering}

The publications related to the flowering of Qualea spp. or Q. grandiflora described the species as monoecious and highly dependent on pollinators, particularly hawkmoths (Sphingidae) but also other moths and wild bees (Barbosa 1983, Paulilo 1991, Van Schaik et al. 1993, Batalha \& Mantovani 2000, Oliveira et al. 2004, Santos \& De Melo Ferreira 2012). The longevity of flowers is only two days (Oliveira et al. 2004). Silberbauer-Gottsberger (2001) reported 70 flowering Q. grandiflora trees per hectare during a one-year period, representing $38 \%$ of all mature Q. grandiflora trees. Over a period of three years the individual treebased study carried out by Potascheff et al. (2019) documented mean annual flower 


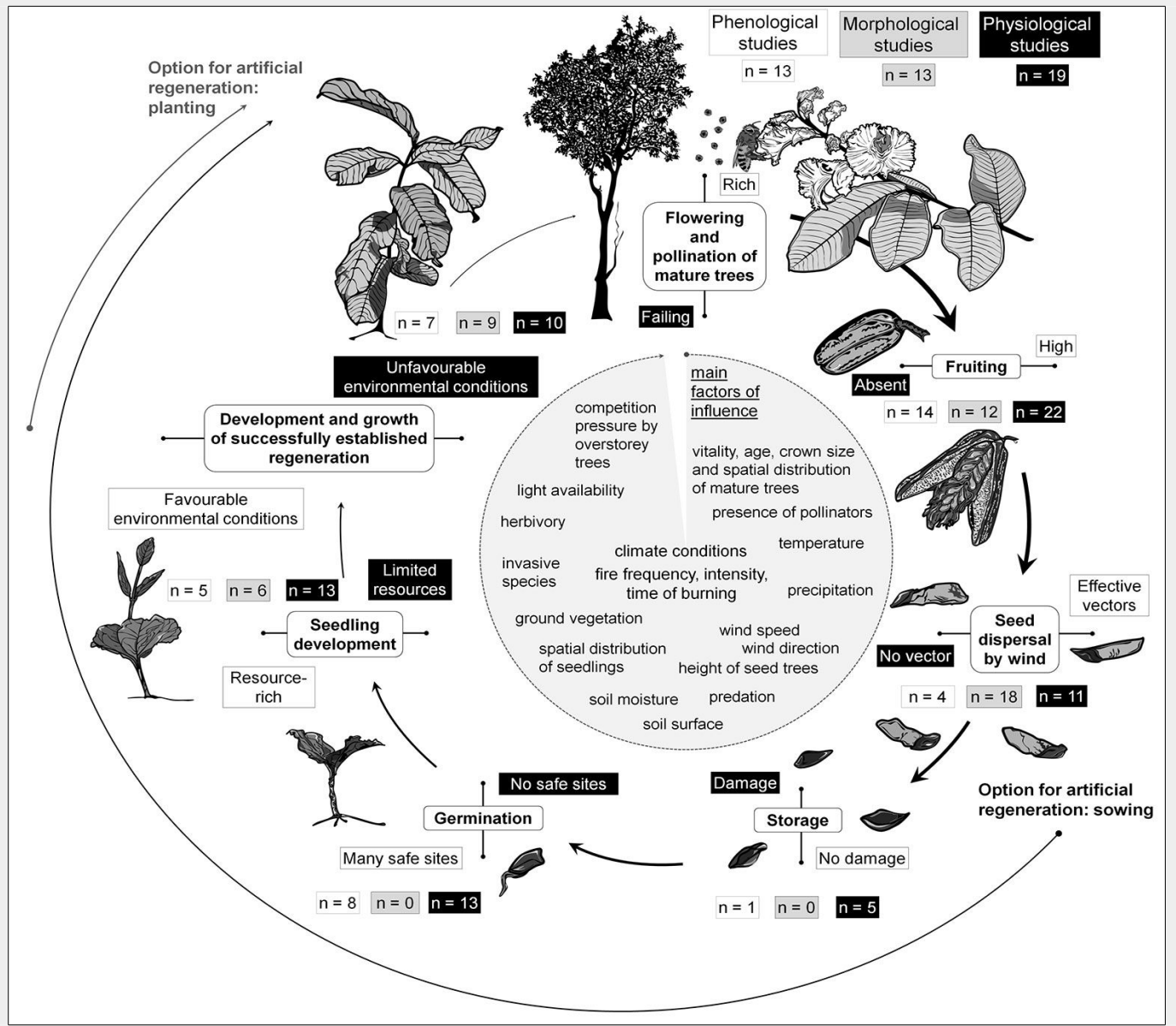

Fig. 4 - Regeneration cycle of Qualea spp. and Q. grandiflora differentiated according to the main development stages and connected processes (reference is a total of 51 publications, but multiple responses were possible for a single publication).

numbers of 109, 635 and 695 per tree. vive in its native ecosystem. The effect of Flowering occurs in the dry period or dur- fire on the flowering of Q. parviflora was ing the transition between the dry and humid periods (Batalha \& Mantovani 2000, Lenza \& Klink 2006, Pirani et al. 2009), and usually the flowering peak is reached quickly and is often synchronised between individual trees (Lenza \& Klink 2006). These characteristics can be considered a strategic adaptation to several biotic and abiotic factors (Van Schaik et al. 1993, Antiqueira \& Kageyama 2014), determined by intrinsic genetic traits (Ritter et al. 2012) allowing the species to reproduce and surshown by Palermo \& Miranda (2012), who observed that no inflorescence was produced one year after fire, suggesting that the species may need more than one year before the normal reproductive cycle can recover. Consequently, fire intensity and the related damage determine the time until regeneration processes such as flowering return to a more regular state. This must be taken into consideration when using fire as a management tool (refer to the discussion). Another study showed flower- ing to be negatively correlated with precipitation (Pirani et al. 2009). This suggests that flowering is induced by rehydration, due to the reduced transpiration brought about by leaf shedding (Borchert 1994). The available information concerning the periods of flowering and fruiting differed between the literature sources (Tab. 1).

\section{Pollination}

The pollination process appears highly successful, given the almost annual flowering (Pirani et al. 2009), and a high viability of the pollen of between $70 \%$ to $97 \%$ (Mor-

Tab. 1 - Phenologically influenced frequency of flowering and fruiting processes in Q. grandiflora according to various sources. (FL): main time of flowering; $(\mathrm{T})$ : transition time of flowering and fruiting; (FR): main time of fruiting; $\left({ }^{*}\right)$ : dry season with precipitation per month < $60 \mathrm{~mm}$ (according to Rawitscher 1948).

\begin{tabular}{|c|c|c|c|c|c|c|c|c|c|c|c|c|c|c|c|}
\hline Authors & $\begin{array}{l}\text { Lat } S \\
\left({ }^{\circ}\right)\end{array}$ & $\begin{array}{c}\text { Long W } \\
\left({ }^{\circ}\right)\end{array}$ & $\begin{array}{l}\text { Altitude } \\
\text { (m a.s.l.) }\end{array}$ & $\begin{array}{l}\Xi \\
\text { ] } \\
\text { T) }\end{array}$ & 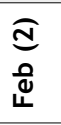 & $\begin{array}{l}\stackrel{0}{2} \\
\frac{1}{2} \\
\frac{\pi}{2}\end{array}$ & $\begin{array}{l}\hat{ \pm} \\
\frac{1}{2}\end{array}$ & 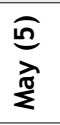 & 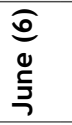 & $\begin{array}{l}\mathbb{E} \\
\frac{2}{3}\end{array}$ & $\begin{array}{l}\underset{\infty}{\infty} \\
\underset{z}{\gtrless}\end{array}$ & $\begin{array}{l}\sigma \\
\stackrel{\sigma}{0} \\
\stackrel{\Delta}{n}\end{array}$ & $\underset{\stackrel{\tilde{U}}{O}}{\stackrel{0}{\Xi}}$ & $\begin{array}{l}\text { I } \\
\text { 을 } \\
\text { z }\end{array}$ & 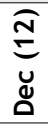 \\
\hline Batalha \& Mantovani (2000) & 21 & 47 & $660-730$ & $\mathrm{FL}$ & $\mathrm{FL}$ & - & - & FR & $\mathrm{FR}^{*}$ & $\mathrm{FR}^{*}$ & $\mathrm{FR}^{*}$ & $T$ & $T$ & $T$ & $\mathrm{~T}$ \\
\hline Kutschenko (2009) & 15 & 47 & $1025-1150$ & $T$ & $\mathrm{~T}$ & $\mathrm{~T}$ & FR & $\mathrm{FR}^{*}$ & $\mathrm{FR}^{*}$ & $\mathrm{FR}^{*}$ & $\mathrm{FR}$ & $\mathrm{FR}^{*}$ & $\mathrm{FL}^{*}$ & $\mathrm{FL}$ & $\mathrm{FL}$ \\
\hline Negrelle (2011) & 25 & 52 & $730-1100$ & $\mathrm{FL}$ & $\mathrm{T}$ & FR & FR & FR & FR & - & - & - & $\mathrm{FL}$ & $\mathrm{FL}$ & FL \\
\hline Pirani et al. (2009) & 15 & 52 & 562 & $T$ & FR & FR & FR & $\mathrm{FR}^{*}$ & $\mathrm{FR}^{*}$ & $\mathrm{FR}^{*}$ & $\mathrm{FR}^{*}$ & - & $\mathrm{T}$ & $\mathrm{FL}$ & $\mathrm{FL}$ \\
\hline Santos \& De Melo Ferreira (2012) & 10 & 48 & 270 & $\mathrm{FL}$ & $\mathrm{T}$ & $\mathrm{T}$ & FR & $\mathrm{FR}^{*}$ & $\mathrm{FR}$ * & $\mathrm{FR}$ * & $\mathrm{FR}^{*}$ & FR & - & $\mathrm{FL}$ & $\mathrm{FL}$ \\
\hline Ribeiro \& Borghetti (2014) & 15 & 47 & 1100 & FR & FR & FR & FR & $\mathrm{FR}^{*}$ & $\mathrm{FR}^{*}$ & $\mathrm{FR}^{*}$ & $\mathrm{FR}^{*}$ & $\mathrm{FR}^{*}$ & * & - & $\mathrm{FR}$ \\
\hline Silberbauer-Gottsberger (2001) & 22 & 48 & $550-700$ & $\mathrm{FL}$ & $\mathrm{FL}$ & - & - & $\mathrm{FR}$ & $\mathrm{FR}$ & $\mathrm{FR}^{*}$ & $\mathrm{FR}^{*}$ & - & - & - & $\mathrm{FL}$ \\
\hline Silvério \& Lenza (2010) & 14 & 52 & 340 & $\mathrm{FL}$ & - & - & - & $\mathrm{FR}^{*}$ & $\mathrm{FR}^{*}$ & $\mathrm{FR}^{*}$ & * & * & - & $\mathrm{FL}$ & $\mathrm{FL}$ \\
\hline Lenza \& Klink (2006) & 15 & 47 & $1045-1146$ & $\mathrm{FL}$ & - & - & - & $*$ & * & $\mathrm{FR}^{*}$ & $\mathrm{FR}^{*}$ & $\mathrm{FR}^{*}$ & $\mathrm{~T}$ & $\mathrm{FL}$ & $\mathrm{FL}$ \\
\hline Paulilo (1991) & 22 & 47 & 760 & $\mathrm{FL}$ & $\mathrm{FL}$ & - & - & - & - & - & - & $\mathrm{T}$ & $\mathrm{FL}$ & $\mathrm{FL}$ & $\mathrm{FL}$ \\
\hline
\end{tabular}


eira et al. 2009, Borges et al. 2011). The dry period favours insect activity, and exemplifies the close plant-insect interaction. Fischer \& Gordo (1993) and Oliveira et al. (2004) showed that in the case of Q. cordata and $Q$. grandiflora it is important to know how close the plant-pollinator interactions are. The authors could prove that the territorial behaviour of pollinators is strongly influenced by the total number of flowers and the distribution of flowering trees. Borges et al. (2011) demonstrated that isolated flowers on an individual tree not visited by pollinators failed to develop fruits, and Barbosa (1983) demonstrated auto-incompatibility in Q. grandiflora. The only study including spatial information about the pollination of Q. grandiflora indicated mean effective dispersal distances of $525 \mathrm{~m}$ for a cerrado landscape in Brazil, with an average distance between mother trees of $566 \mathrm{~m}$ (Potascheff et al. 2019). The same study showed that outcrossing rates were high, and that mating amongst relatives and selfing correlations were low.

\section{Fruiting}

According to Borges et al. (2011), trees start fruiting at an average diameter at breast height $(\mathrm{DBH})$ of $22 \mathrm{~cm}$. Based on the very limited dendrochronology research to date, it can be assumed that a Q. grandiflora tree with this diameter is approximately 25 to 30 years old (Leite et al. 2016). However, Q. grandiflora trees of smaller dimensions have also been seen bearing fruit (personal observation, Da Ponte 2018). In the study by Borges et al. (2011), a weak positive correlation was revealed between $\mathrm{DBH}$ and the number of fruits produced per tree. It may be assumed, therefore, that individuals of a higher diameter produce more fruits. The number of $Q$. grandiflora trees with ripe fruits during the year may reach 20 trees per hectare, or $11 \%$ of all mature trees (Silberbauer-Gottsberger 2001). Observing the initial processes of fruiting in Q. grandiflora, Barbosa (1983) recorded a relationship between flowers/ buds of $32.1 \%$, compared to $0.8 \%$ for fruits/ flowers. Silberbauer-Gottsberger (2001) documented a fruit/flower relationship of $28.6 \%$. The rhythm of fruiting in the cerrado is more strongly linked to the seasonal climate than is the case for flowering and pollination (Silberbauer-Gottsberger 2001). Oliveira et al. (2004) described the amount of fruiting as highly variable between years. They observed high fructification rates for Q. grandiflora, with two years of fruit production followed by a year with almost no fruit. The production of fruit by anemochorous species in the cerrado formations is significantly negatively correlated with precipitation but significantly positively correlated with temperature ( $\mathrm{Pi}$ rani et al. 2009). This phenomenon was described for Q. grandiflora and other species, especially wind dispersed tree species (Van Schaik et al. 1993). Most of the anemochorous species (e.g., Kielmeyera cori- acea, Cochlospermum religiosum, Dalbergia miscolobium) of the cerrado produce fruits during the dry period, reaching their peak in August and September (Batalha \& Mantovani 2000, Lenza \& Klink 2006, Pirani et al. 2009, Salazar et al. 2012). Most of the studies mentioned that fruiting takes place during the period April to September (Tab. 1). Q. grandiflora has fruits that protect seeds from burning (Coutinho 1982), but fire is not necessary for the opening of fruits and seed release.

\section{Seed characteristics and dispersal}

The literature review revealed that studies conducted on Q. grandiflora seeds are rare (Dousseau et al. 2013). Most such studies (Fig. 4) were concerned with descriptions of morphological seed characteristics (Ferreira et al. 2001, Kutschenko 2009, Ribeiro \& Borghetti 2014). The studies showed damage to between $20 \%$ and $60 \%$ of seeds, caused mainly by Buprestidae and Hymenoptera (Custódio et al. 2014). The available information on seed dispersal in Q. grandiflora is limited to the written description of anemochorous seed dispersal mechanisms (Oliveira \& Moreira 1992, Lacerda Resende 2003, Luz et al. 2008, Jardim \& Batalha 2009, Ragusa-Netto \& Santos 2015). Typically, seed dispersal takes place during the dry period, with low air humidity, increasing wind velocity and decreasing leaf cover (Batalha \& Mantovani 2000, Vieira et al. 2008).

According to Augspurger (1986), the seeds of Q. grandiflora are comparable in size and weight to those of the species $\mathrm{Ce}$ drela odorata (Meliaceae), and consequently the estimated dispersal distances are $103 \mathrm{~m}$ to $410 \mathrm{~m}$. Salazar et al. (2012) documented a mean seed density of 0.9 seeds per $\mathrm{m}^{2}$ in a campo sujo formation, but the authors collected no seeds in the cerrado sensu stricto formation. A detailed analysis of Q. grandiflora seed dispersal distances using seed traps was performed by Da Ponte (2018) within the Mbaracayú Nature Forest Reserve in eastern Paraguay, where mean dispersal distances of between 11 and $62 \mathrm{~m}$ were determined.

\section{Seed storage}

According to De Melo et al. (1979) and Dousseau et al. (2013), seeds of Q. grandiflora possess dormancy. Germination was observed to increase to $60 \%$ after seed storage, compared to $10 \%$ without storage. Rizzini (1965) mentioned the importance of seed storage in the cerrado biomes to bridge periods of harsh conditions, including arid soil surfaces, prolonged periods of drought and, above all, fire. Ribeiro \& Borghetti (2014) demonstrated the high tolerance of $Q$. grandiflora seeds to heat shocks of between 80 to $140{ }^{\circ} \mathrm{C}$. This resistance to high temperatures is necessary because of the occurrence of air and soil surface temperatures of up to $350{ }^{\circ} \mathrm{C}$ during fire, depending on the fuel load (Miranda et al. 1993). However, fire can also promote germination by breaking seed dormancy (Bilio et al. 2013, Ribeiro \& Borghetti 2014). The observed seed attributes and seed mass, therefore, increase seeds' tolerance to environmental stress and are likely to contribute to the recruitment of the tree species in the harsh environments of the cerrado (Bond \& Keeley 2005, Ribeiro \& Borghetti 2014). Assessments of the effects of seed predation revealed that more that $95 \%$ of Q. grandiflora seeds and fruits may be damaged by parrots or insects in open and closed woodland savannas (De Faria et al. 2007, Salazar 2010).

\section{Germination and development of early seedling stages}

The germination process of Q. grandiflora is assigned to the phanecotylar-epigeous type of germination (Ferreira et al. 2001). This means that the cotyledons are lifted above the soil surface. To increase the likelihood of successful germination in cerrado formations, and to survive the first seedling stages, tree species like Q. grandiflora disperse their seeds during the dry period, but shortly before the transition to the humid season begins. Q. grandiflora seedlings that emerge at the beginning of the rainy season develop more successfully due to the optimal soil moisture conditions (Tab. 1). Ribeiro \& Borghetti (2014) demonstrated the great tolerance of Q. grandiflora seeds to extremely high temperatures and desiccation, achieving high germination rates of $63 \%$ to $71 \%$. Experimental studies by Bilio et al. (2013) and Dousseau et al. (2013) showed that temperatures of 25 to $30{ }^{\circ} \mathrm{C}$ lead to the highest germination rates under controlled conditions, irrespective of the presence or absence of light (Zaidan \& Carreira 2008). In order to survive, seedlings must develop deep roots before the next dry season starts (Rizzini 1965, Salazar 2010). The rate of shoot growth is typically slow compared to the fast root growth occurring during the first months of seedling development (Rizzini 1965). This may provide an explanation for the supposedly lower seedling and sapling establishment potential of Q. grandiflora, as it might suggest higher competitiveness of other, in some cases invasive species. Although Q. grandiflora has a high level of tolerance in terms of irradiation and soil nutrients as these affect seed germination and initial seedling growth, Klein (2000) revealed that seeds of Q. grandiflora often achieve germination rates of less than $20 \%$ under natural conditions in the cerrado. Costa \& Franco (2007), by contrast, found higher germination rates in cerrado formations covered by ground vegetation comprising herbs and shrubs, which facilitate the germination process by providing small-scale shelter effects. Litter, ground vegetation and canopy cover exert an influence on germination and early seedling development, yet these factors are also affected by fire (Bond \& Keeley 2005). Fire also results in an immediate flush of nutrients, while in the long- 
Tab. 2 - Summary of the ecological bottlenecks, research gaps and suggestions for silviculture for each reproduction stage.

\begin{tabular}{|c|c|c|c|}
\hline $\begin{array}{l}\text { Regeneration } \\
\text { stage }\end{array}$ & $\begin{array}{l}\text { Identified ecological } \\
\text { bottlenecks }\end{array}$ & $\begin{array}{l}\text { Research gaps within the } \\
\text { regeneration cycle }\end{array}$ & Suggestions for silviculture \\
\hline Flowering & $\begin{array}{l}\text { - extremes in rainy seasons (El } \\
\text { Niño) } \\
\text { - intensive crown fires }\end{array}$ & $\begin{array}{l}\text { - age, size and vitality related } \\
\text { flowering information for individual } \\
\text { trees, effects of drought and fire } \\
\text { - spatial information (spatial } \\
\text { distribution patterns, distances } \\
\text { between trees) }\end{array}$ & $\begin{array}{l}\text { - promotion of potential seed trees by } \\
\text { continuous crown tending } \\
\text { - regulation of the spatial distribution of } \\
\text { flowering trees on local and regional scale } \\
\text { to guarantee genetic exchange }\end{array}$ \\
\hline Pollination & $\begin{array}{l}\text { - low number of mature trees in } \\
\text { local populations } \\
\text { - missing pollinators } \\
\text { - intensive crown fires }\end{array}$ & $\begin{array}{l}\text { - range of pollinator species and } \\
\text { numbers of individuals } \\
\text { - detailed information about } \\
\text { habitats, lifecycles and behaviour } \\
\text { of pollinator species }\end{array}$ & $\begin{array}{l}\text { - ensure an adequate number and distribution } \\
\text { of mature trees } \\
\text { - support pollinating moths, bees and } \\
\text { hummingbirds by establishing areas with } \\
\text { dense sub-canopy structures as refuges } \\
\text { - protect endemic flowering tree species }\end{array}$ \\
\hline Fruiting & $\begin{array}{l}\text { - calamities of seed predating } \\
\text { insects } \\
\text { - intensive crown fires }\end{array}$ & $\begin{array}{l}\text { - quantity of fruits and seeds } \\
\text { damaged by fire events } \\
\text { - age, size and vitality related } \\
\text { fruiting information for individual } \\
\text { trees }\end{array}$ & $\begin{array}{l}\text { - preservation of a sufficient number of seed } \\
\text { producing trees } \\
\text { - regulation of the spatial distribution of seed } \\
\text { trees } \\
\text { - seed collection in regions with high } \\
\text { quantities of seed and for known } \\
\text { provenances to implement direct seeding or } \\
\text { plant propagation }\end{array}$ \\
\hline Seed dispersal & $\begin{array}{l}\text { - heavy rainfall events } \\
\text { - high proportions of diaspore } \\
\text { damage }\end{array}$ & $\begin{array}{l}\text { - mean and maximum dispersal } \\
\text { distances and densities related to } \\
\text { individual tree parameters } \\
\text { - quantification of direct wind } \\
\text { effects (e.g., wind speed, wind } \\
\text { direction) }\end{array}$ & $\begin{array}{l}\text { - long-term determination of seed source } \\
\text { locations (see above) } \\
\text { - aggregate or regular seed distributions can } \\
\text { be controlled by combining seed tree } \\
\text { positions and wind parameters }\end{array}$ \\
\hline Seed storage & $\begin{array}{l}\text { - calamities of seed predating } \\
\text { insects } \\
\text { - intensive and frequent ground } \\
\text { fires }\end{array}$ & $\begin{array}{l}\text { - seed storage under field conditions } \\
\text { (predation, influence of fire, depth } \\
\text { of soil layer) } \\
\text { - causes of viability loss of stored } \\
\text { seeds }\end{array}$ & $\begin{array}{l}\text { - preparation of suitable surface conditions } \\
\text { (e.g., low intensity fire, soil scarification) } \\
\text { before seed dispersal, concentrated on } \\
\text { potential deposition sites surrounding seed } \\
\text { trees }\end{array}$ \\
\hline Germination & $\begin{array}{l}\text { - calamities of seed predating } \\
\text { insects } \\
\text { - intensive and frequent ground } \\
\text { fires } \\
\text { - invasive species as } \\
\text { competitors }\end{array}$ & $\begin{array}{l}\text { - fire effects on seed germination } \\
\text { safe site characteristics, } \\
\text { competitors and facilitation plants }\end{array}$ & $\begin{array}{l}\text { - break dormancy of deposited seeds by low } \\
\text { intensity surface fires } \\
\text { - reduce competing ground vegetation, } \\
\text { especially grasses (surface fire, soil } \\
\text { scarification, canopy cover or light grazing) }\end{array}$ \\
\hline $\begin{array}{l}\text { Seedling } \\
\text { establishment } \\
\text { and development }\end{array}$ & $\begin{array}{l}\text { - intensive ground fires } \\
\text { - extremely long-term drought } \\
\text { - invasive species as } \\
\text { competitors } \\
\text { - intensive herbivory }\end{array}$ & $\begin{array}{l}\text { - temporal and spatial } \\
\text { documentation of seedling } \\
\text { establishment (density, distribution } \\
\text { patterns) and growth (above- and } \\
\text { below-ground) }\end{array}$ & $\begin{array}{l}\text { direct (e.g., low intensity surface fires, } \\
\text { mulching, mowing or light grazing) or } \\
\text { indirect (suppression of light demanding } \\
\text { competitors by regulating the shelter of } \\
\text { canopy trees) regulation of interspecific } \\
\text { competition, especially of invasive species }\end{array}$ \\
\hline $\begin{array}{l}\text { Development } \\
\text { and growth of } \\
\text { successfully } \\
\text { established } \\
\text { young trees }\end{array}$ & $\begin{array}{l}\text { - continuous influence of } \\
\text { competitive invasive species } \\
\text { extremely long drought } \\
\text { periods } \\
\text { - continuous and intensive } \\
\text { herbivory }\end{array}$ & $\begin{array}{l}\text { - age and diameter frequency } \\
\text { distributions } \\
\text { - documentation of growth } \\
\text { parameters under different } \\
\text { conditions (light availability, inter- } \\
\text { and intraspecific competition) } \\
\text { - options for regulation of } \\
\text { competition exerted by invasive } \\
\text { species, e.g., using fire }\end{array}$ & $\begin{array}{l}\text { - regulation of interspecific competition } \\
\text { - cuttings within the overstorey tree layer to } \\
\text { regulate light availability and to reduce } \\
\text { water stress } \\
\text { - low intensity surface fires guarantee re- } \\
\text { sprouting of established regeneration }\end{array}$ \\
\hline
\end{tabular}

term leading to losses of phosphorus, nitrogen and sulphur.

\section{Development and growth of} established young trees

According to Eiten (1972), the growth of established Q. grandiflora seedlings may be influenced primarily by adaptation features developed in order to survive in the harsh conditions of the cerrado rather than under sheltered conditions beneath the canopy. Paulilo et al. (1998) emphasised the importance of water availability for further growth, biomass and leaf area develop- ment in Q. grandiflora. As a deciduous tree, Q. grandiflora can shed its leaves under water stress during the dry season, with new shoots emerging again later on during the wet season (Reich \& Borchert 1984). Adaptations of young $Q$. grandiflora to limited water and nutrient availability in the cerrado ecosystem are the early development of deep taproots and the reduction of stomatal conductance (Eiten 1972, Paulilo et al. 1998). This deep taproot development and the high capacity for re-sprouting (vegetative reproduction) are also crucial to compensate for damage caused by fire as demonstrated in various studies of the genus Vochysia and other savanna tree species (Rizzini 1965, Bond \& Keeley 2005). Whereas Q. grandiflora can reach higher regeneration densities in unburned than burned areas, mortality as a consequence of intraspecific competition does not appear to be an important aspect in the dynamic of this species (Costa \& Santos 2011). Studies by Lima-Ribeiro (2007) and Costa \& Santos (2011) revealed that the abundance of Q. grandiflora ranges between 80 to 147 and 36 to 638 individuals per hectare, respectively. 
In a typical cerradão formation the relative light availability ranges between $20 \%$ to 30\% (Hoffmann \& Franco 2003). Although this level of light availability is not directly relevant for the survival of established young Q. grandiflora plants, it does affect the absolute growth rate of young plants, biomass partitioning (resource allocation), carbon assimilation rates, morphological plasticity and, finally, their interspecific competitiveness as demonstrated by $\mathrm{Fe}$ lippe \& Dale (1990). A high degree of plasticity has been described for Q. grandiflora in terms of the different formations in the cerrado biome (from the campo cerrado to the cerradão).

The below-ground biomass of tree species is typically very high in cerrado ecosystems (Rawitscher 1948, Paulilo 1991, Moreira \& Klink 2000, Ferreira et al. 2007), but more than $80 \%$ of the root biomass occurs in the upper $30 \mathrm{~cm}$ of the soil (Rizzini 1965).

Only three studies addressed the question of the spatial distribution characteristics of tree species in the cerrado biome. Studies carried out in different municipalities in Brazil revealed that individuals of $Q$. grandiflora with a DBH greater than $3 \mathrm{~cm}$ have a tendency towards spatially aggregated distributions (Durigan et al. 2002, Rosseto et al. 2005). Costa \& Santos (2011) observed a trend in the patterns of spatial distribution for Q. grandiflora dependent on the different cerrado formations. Q. grandiflora would appear to follow a more aggregated distribution pattern in open cerrado formations (Fig. 1), whereas in dense forest formations young and adult Q. grandiflora trees show a greater range of variation, from random spatial patterns to aggregated (Costa \& Santos 2011).

\section{Discussion}

After a summary of the available processand stage-specific information concerning the regeneration cycle of Q. grandiflora, the following section contains a discussion of those aspects that can be included in strategies for the silvicultural management or conservation of the species (Tab. 2). It is particularly useful to follow again the chronology of the regeneration cycle in order to critically scrutinise the available information and to highlight which additional information would be helpful to enhance the regeneration success of $Q$. grandiflora in the cerrado biome.

It was shown that the fruit/flower relationship is characterised by extremely variable production of fruits relative to the numbers of flowers. The presence of pathogens responsible for damage to flower buds could be one explanation for the aforementioned high flower/bud ratio, whereas the low ratio of fruits/flowers may be explained by the absence of pollinators (see above, Borges et al. 2011). Considering the close interaction between insects and the success of pollination of Q. grandiflora (Barbosa 1983, Silberbauer-Gottsberger
2001), indirect measures taken to support the specific habitat requirements of pollinating insects are conceivable (e.g., moths, wild bees or hummingbirds). Studies focused on flowering and pollination are of practical relevance as information at the individual tree level (e.g., age-dependent flowering or fructification, tree vitality, crown and stem dimensions) is rare (Silberbauer-Gottsberger 2001). Recent studies either focused only on individual growth parameters and age determination (Leite et al. 2016) or on genetic parameters within the regeneration cycle of $Q$. grandiflora (Potascheff et al. 2019). Although these studies represent a very important contribution to the field of species-specific regeneration in the cerrado formations, the combination of both aspects should be undertaken.

Another important aspect connected with pollination mechanisms at different spatial scales is the question of distancedependence and the spatial distribution of flowering trees. Some initial findings have been produced by means of genetic analyses, an important tool for use in future studies to enhance the current knowledge of pollination and flowering (Antiqueira \& Kageyama 2015). The case study by Potascheff et al. (2019) conveys a first impression of pollen distances and related genetic traits. By analysing spatial information, we may be able to identify the critical distances between flowering trees necessary to ensure the successful regeneration of $Q$. grandiflora within different cerrado formations or across different spatial scales (Jardim \& Batalha 2009, Camilotti et al. 2011). This information on maximum allowable distances between vital, mature $Q$. grandiflora trees is necessary for the development of successful conservation management strategies. Replicated documentation of local and regional flowering and fruiting frequencies, their success and the main factors of influence (biotic or abiotic) can provide an idea of the feasibility and possible limitations of proposed measures; for example, application of optimal fire management strategies to avoid fragmentation (Roitman et al. 2008). Fire may affect important pollinators, either direct fire-induced mortality or indirectly by limiting flower resources (Hermann et al. 1998). The global analysis of the effects of fire on pollinators published by Carbone et al. (2019) revealed that wildfires and prescribed fires have different effects on different pollinator groups. Whereas habitat specialists such as butterflies and bird species fall in abundance, other pollinator groups such as Hymenoptera or Diptera are positively affected. But the authors stated that publications of these pollinator groups related to Q. grandiflora are particularly limited. The timing of fire and the burn frequency may have different impacts on pollinator guilds and should, therefore, be explored. Invasive plants (e.g., Melinis minutiflora, Brachiaria decumbens or Pteridium aquilinum) and their future management would appear to exert a great influence on pollination interactions and associations in cerrado biomes (Hoffmann et al. 2004), because of the displacement of flowering endemic species, absent functional floral traits and the related interruption of plantpollinator interactions (Carstensen et al. 2016).

The preservation of a sufficient number of potential seed trees of high vitality is one means to guarantee regeneration, but preliminary information about the natural ecosystem structure is needed to decide on sustainable measures appropriate within the current situations prevailing in cerrado formations (Khurana \& Singh 2001). Although the density of trees is low in most cerrado formations, one option might be to consider whether mature individual trees of Q. grandiflora in dense cerradão formations would benefit from a reduction of inter- or intraspecific competition caused by other tree species or crownenveloping species such as vines and lianas (Oliveira \& Marquis 2002).

Important information about seed dispersal, a key process with implications for, e.g., the deposited seed densities, and dispersal distances and directions, is only infrequently available for Qualea spp. generally and Q. grandiflora in particular (Salazar et al. 2012). Such information about distance-dependent seed densities and directions may be considered basic ecological information. This information would help silviculturists and local managers to estimate the probability of regeneration, and the subsequent spatial distribution of $Q$. grandiflora. In combination with empirical sampling of annual seed production at local scales, this information would make possible inferences about the long-term development of species-specific seed production. Should continuously low dispersal rates or locally isolated seed dispersal be observed in cerrado formations, additional controlled input of Q. grandiflora seeds or planting of known provenances could be undertaken as part of silvicultural management activities (Pellizzaro et al. 2017). Appropriate locations must be selected or additional measures to push back the competing ground vegetation must be examined (see below). Provisional results of the first direct seeding experiments revealed low success for Q. grandiflora (Pellizzaro et al. 2017). Regular tests of local and regional seed quality can help to identify the main reasons for seed damage and give an idea of the species-specific potential to germinate successfully. Given the seed dormancy-breaking function of fire, silvicultural activities have to adapt fire management to allow surface fires with low intensities (Walters et al. 2004). The information on seed dispersal and the safe sites required for germination suggest it would be expedient to concentrate these low intensity burns around mature trees or tree groups of the respective target species, for exam- 
ple, Q. grandiflora. The seeds of flat-seeded species such as Q. grandiflora should not be buried. Mulching appears the best site preparation as seedling emergence is higher on mulched sites than where seeds are uncovered (Silva \& Vieira 2017).

The transition process from seed to seedling is one of the highest risk periods in the lifecycle of most plants, and the capacity of a seed to tolerate stress conditions is fundamental for germination and recruitment under harsh environmental conditions (Ferreira et al. 2007). There is a high degree of small-scale heterogeneity in soil moisture, which is critical for germination and to the success of the earliest development stages of seedlings (Ferreira et al. 2007, Pellizzaro et al. 2017). Surface fires have been described as ecological bottlenecks, reducing seedling density, but preserving saplings (Bond \& Keeley 2005, Norden et al. 2009). To enhance the success of $Q$. grandiflora during the process of germination and seedling development, the positive effects of surface fires (reduction of competing ground vegetation cover, increase of direct irradiation and temperatures) can be used, but the timing of fire initiation appears to be the most crucial management factor beside fire intensity. Periodic burns implemented as a silvicultural management strategy may help to maintain plant diversity, protect plants from disease and allow perennial grasses and herbaceous plants promoting the establishment of Q. grandiflora seedlings (Waldrop et al. 1992). Another option to regulate competition from invasive grasses is light grazing by livestock with a preference for invasive species (e.g., African grass, Melinis minutiflora - Hoffmann et al. 2004).

Little is known about the capacity of $Q$. grandiflora to re-sprout and the potential application of management employing coppice systems as an adaptation strategy to stimulate and increase the aboveground development and competitiveness of trees (Vieira et al. 2008). However, it has been suggested that, compared to other cerrado species, $Q$. grandiflora is sensitive to disturbances, especially fire (De Faria Lopes et al. 2009), as only the aboveground parts of young plants (e.g., shoots) are able to re-sprout (Medeiros \& Miranda 2008). The regeneration of Q. grandiflora in cerrado formations could be enhanced by prescribed wet-season fires with the purpose of burning small areas or patches that may contribute to the creation of a mosaic of low-fuel patches and function as natural firebreaks reducing the spread of subsequent fires (Ramos-Neto \& Pivello 2000) and the same time avoid the continuous spread of invasive species (Pivello et al. 2018). In terms of traditional silvicultural management, the relatively low tree densities do not necessitate measures of intraspecific competition regulation. Intensive interspecific competition can be assumed to be more relevant for this developmental stage of cerrado tree species, es- pecially in the cerradão formation (Soares et al. 2006).

Although the influence of shelter trees has been described for Q. grandiflora (Eiten 1972), no growth parameters directly related to the canopy cover provided by shelter trees or to light measurements are available. Therefore, silvicultural measures in cerradão formations where the number of Q. grandiflora seedlings is underrepresented but sufficient seed trees are present, should be oriented towards selective felling of individual trees or the felling of small groups within the dominant tree layer. The establishment of small canopy gaps is also expedient where a dense layer of naturally regenerated Q. grandiflora is present, but these plants show obvious poor growth. Low vitality and growth can be caused by low light availability or severe water stress, influenced by directly competing overstorey trees. Although Ferreira et al. (2007) observed a positive relationship between water availability and the structural attributes of the vegetation, seedlings and juvenile plants of Q. grandiflora are exposed to high competition pressure by larger trees.

There are multiple reasons for species or age specific differences in the spatial distribution patterns of cerrado trees, yet none have been investigated. A lot of traditional silvicultural management systems are based on spatial information regarding the stages and processes within the regeneration cycle of tree species. As already mentioned, planning and practical management of natural regeneration in silviculture necessitate spatial information about seed trees, seed dispersal, predation and seedling establishment (Nyland 2002). Almost all ecological processes in regeneration ecology are determined by spatial and temporal factors, and can only be controlled and assessed by silvicultural measures adapted to time and space.

\section{Conclusions}

Using the intensive literature review as a first analysis step, it was determined that a lot of important details concerning the regeneration cycle of cerrado tree species such as Q. grandiflora are available. In the second step we identified the main factors influencing the success of regeneration and pointed out the stage-specific risks. The influence of the fire regime would appear to be very important for all regeneration stages and processes in Q. grandiflora. Given the long history of human impact, in the form of rising population densities, increasing farming activities and fragmentation of the cerrado biome and surrounding areas, it is difficult to determine the natural fire regime (Jepson et al. 2010). It has been proven that Q. grandiflora and Qualea spp. are more sensitive to fire than other woody species in the cerrado biome, and that their abundance decreases in intensively burned areas (Medeiros \& Miranda 2008, De Faria Lopes et al. 2009). Small fires during the wet season are advantageous for the successful regeneration of tree species such as Q. grandiflora (RamosNeto \& Pivello 2000). Although there has been a lot of research related to the fire regime in the cerrado biome, species-specific and goal-oriented field experiments are still missing (Ramos-Neto \& Pivello 2000). Any such experiments should consider the different key variables of the fire regime and the regeneration stages of tree species such as Q. grandiflora (e.g., fire and vegetation dependent storage and seeding experiments) to develop concrete strategies with practical relevance. Prescribed burning measures to promote regeneration of Q. grandiflora should consider the time of year, the time since the last rainfall event and the amount of accumulated fuel to ensure success (Ramos-Neto \& Pivello 2000). Many important aspects of the life stages and processes remain unknown or wholly theory-based (Dousseau et al. 2013). Where it to be available, information on features such as age or diameter frequency distributions could be used to derive a characteristic quantitative relationship between adult trees and the younger developmental stages of healthy populations in a typical cerrado formation. This information is needed as a proxy for whether a tree species needs active management intervention or not. One such example was presented for the cerrado biome by Oliveira \& Marquis (2002), at the level of cerrado formations and functional groups of species rather than on a species level. By comparing tree species in this way, and considering, for example, different local climate and soil conditions or fire frequencies, it is possible to characterise the species' behaviour as controlled by abiotic environmental factors or interspecific competition, especially in the context of increasing competition from invasive species in neotropical savanna biomes.

\section{Funding information}

This literature review was carried out within the framework of a PhD study funded with a research grant provided by the DAAD (German Academic Exchange Service). A special thanks goes to our proof reader, David Butler Manning.

\section{References}

Antiqueira LMOR, Kageyama PY (2014). Genetic diversity of four populations of Qualea grandiflora Mart. in fragments of the Brazilian Cerrado. Genetica 142: 11-21. - doi: 10.1007/s10709013-9750-5

Antiqueira LMOR, Kageyama PY (2015). Reproductive system and pollen flow in progenies of Qualea grandiflora Mart., a typical species of the Brazilian cerrado. Revista Árvore, ViçosaMG 39: 337-344. - doi: 10.1590/0100-6762201500 0200013

Augspurger CK (1986). Morphology and dispersal potential of wind-dispersed diaspores of neotropical trees. American Journal of Botany 73: 353-363. - doi: 10.1002/j.1537-2197.1986.tb120 
$48 . x$

Barbosa AA (1983). Aspectos da ecologia reprodutiva de tres especies de Qualea (Vochysiaceae) um cerrado de Brasilia, D.F. [Aspects of reproductive ecology of tree species Qualea (Vochysiaceae) in a cerrado ecosystem in Brasilia, D.F.]. MSc thesis, Departamento de Biologia vegetal, Universidade de Brasília, Brazil, pp. 92. [in Portuguese]

Batalha MA, Mantovani W (2000). Reproductive phenological patterns of cerrado plant species at the Pé-de-Gigante Reserve (Santa Rita do Passa Quatro, SP, Brazil): a comparison between the herbaceous and woody floras. Revista Brasileira de Biologia 60: 129-145. - doi: 10.1590/S0034-71082000000100016

Bhadouria R, Singh R, Srivastava P, Raghubanshi AS (2016). Understanding the ecology of treeseedling growth in dry tropical environment: a management perspective. Energy Ecology and Environment 1 (5): 296-309. - doi: 10.1007/s409 74-016-0038-3

Bilio RS, Sebastião CG, Caldeira SF (2013). Qualea grandiflora Mart.: temperatura na germinabilidae de sementes [Qualea grandiflora Mart.: temperature in seed germination]. Ciência Florestal 23: 245-251. [in Portuguese] - doi: 10.5902/ 198050988458

Bond W, Keeley J (2005). Fire as a global "herbivore": the ecology and evolution of flammable ecosystems. Trends in Ecology and Evolution 20: 387-394. - doi: 10.1016/j.tree.2005.04.025 Borchert R (1994). Soil and stem water storage determine phenology and distribution of tropical dry forest trees. Ecology 75: 1437-1449. - doi: 10.2307/1937467

Borges DNAF, Lopes DL, Da Silva De Jesus EB, Dos Santos ML (2011). Sucesso reprodutivo de Qualea grandiflora Mart. (Vochysiaceae) em um fragmento de cerrado sentido restrito no campus da universidade estadual de Goiás, Anápolis, Brasi. [Reproductive success of Qualea grandiflora Mart. (Vochysiaceae) in a fragment of cerrado (sensu stricto) in the Campus of the State University of Goiás, Anápolis, Brazil]. In: "Anais do IX Seminário de Iniciação Científica, VI Jornada de Pesquisa e Pós-Graduação e Semana Nacional de Ciência e Tecnologia". Universidade Estadual des Goiás (Brazil) 19-21 Oct 2011, Goiás, Brazil, pp. 1-5. [in Portuguese]

Camilotti DC, Pagotto TCS, Araujo AC (2011). Análise da vegetação arbórea de um remanescente de Cerradão em Bandeirantes, Mato Grosso do Sul, Brasil [Analysis of the arboreal vegetation of a remnant area of a cerradão in Bandeirantes, Mato Grosso do Sul, Brazil]. Iheringia, Séria Botanica, Porto Alegre 66: 3146. [in Portuguese]

Carbone LM, Tavella J, Pausas JG, Aguilar R (2019). A global synthesis of fire effects on pollinators. Global Ecology and Biogeography 28 (10): 1487-1498. - doi: 10.1111/geb.12939

Carmo-Oliveira R, De Morretes BL (2009). Stigmatic surface in the Vochysiaceae: reproductive and taxonomic implications. Acta Botanica Brasilica 23: 780-785. - doi: 10.1590/S0102-3306 2009000300018

Carstensen DW, Sabatino M, Morellato LPC (2016). Modularity, pollination systems, and interaction turnover in plant-pollinator networks across space. Ecology 97 (5): 1298-1306. - doi:
10.1890/15-0830.1

Costa JVM, Franco AC (2007). Estabelecimento de Qualea grandiflora Mart. e Kielemeyera coriacea Mart. e seu comportamento sazonal em duas fitofisionomias típicas dos cerrados do Brasil central [Establishment of Qualea grandiflora Mart. and Kielemeyera coriacea Mart. and their seasonal behavior in two typical vegetation types of cerrado ecosystems central Brazil]. In: "Anais do VIII Congresso de Ecologia do Brasil", Caxambu (MG, Brazil), 23-28 Sept 2007, pp. 1-2. [in Portuguese]

Costa RC, Santos FAM (2011). Padrões espaciais de Qualea grandiflora Mart. em fragmentos de cerrado no estado de São Paulo. [Spatial patterns of Qualea grandiflora Mart. in cerrado fragments in São Paulo state] Acta Botanica Brasilica 25: 215-222. [in Portuguese] - doi: 10.1590/S0102-33062011000100025

Coutinho LM (1982). Ecological effects of fire in Brazilian cerrado. In: "Ecology of Tropical Savannas" (Billings WD, Golley F, Lange OL, Olson JS, Remmert H, Huntley BJ, Walker BH eds). Ecological Studies, vol. 42, Springer, Berlin, Heidelberg, Germany, pp. 273-291. - doi: 10.1007/9 78-3-642-68786-0_13

Custódio LN, Carmo-Oliveira R, Mendes-Rodrigues C, Oliveira PE (2014). Pre-dispersal seed predation and abortion in species of Callisthene and Qualea (Vochysiaceae) in a Neotropical savanna. Acta Botanica Brasilica 28: 309-320. doi: 10.1590/0102-33062014abb3064

Da Ponte G (2018). Regeneration ecology of anemochorous tree species Qualea grandiflora (Mart.) and Aspidosperma tomentosum (Mart.) of the cerrado Aguara Nu located in the Mbaracayú Nature Forest Reserve (MNFR), Paraguay. $\mathrm{PhD}$ thesis, Institute of Silviculture and Forest Protection, University of Technology Dresden, Germany, pp. 176.

De Faria IP, Dos Santos Abreu TL, Bianchi CA (2007). Seed and fruit predation of Kielmeyera (Guttiferae) and Qualea (Vochysiaceae) species by six psittacid species in the Brazilian cerrado. Ecotropica 13: 75-79. [online] URL: http://www. researchgate.net/publication/262523954

De Faria Lopes S, Do Vale VS, Schiavini I (2009). Efeito de Queimadas sobre a estrutura e composição da comunidade vegetal lenhosa do cerrado sentido restrito em Caldas Novas, GO [Burning effect on structure and composition of the woody plant community of cerrado (sensu stricto) in Caldas Novas Goiás]. Revista Árvore, Viçosa-MG 33: 695-704. [in Portuguese] doi: 10.1590/S0100-67622009000400012

De Melo JT, Ribeiro JF, De Freitas Lima VL (1979). Germinação de sementes de algumas espécies arbóreas nativas do Cerrado [Germination of seeds of some native woody species of cerrado]. Revista Brasileira de Sementes 1: 812. [in Portuguese] - doi: 10.17801/0101-3122/rbs. v1n2p8-12

Dousseau S, De Alvarenga AA, De Oliveira Arantes L, De Souza Chaves I, Avelino EV (2013). Technology of Qualea grandiflora Mart. (Vochysiaceae) seeds. Cerne, Lavras 19: 93-101. - doi: 10.1590/S0104-77602013000100012

Durigan G, Nishikawa DLL, Rocha E, Silveira ER, Pulitano FM, Regalado LB, Carvalhaes MA, Paranaguá PA, Ranieri VEL (2002). Caracterização de dois estratos da vegetação em uma área de cerrado no município de Brotas, SP, Brasil [Characterisation of two vegetation layers in a cerrado area in Brotas municipality, São Paulo, Brazil]. Acta Botanica Brasilica 16: 251-262. [in Portuguese] - doi: 10.1590/S0102-330620020003 00002

Eiten G (1972). The cerrado vegetation of Brazil. The Botanical Review 38: 201-341. - doi: 10.1007/ BF02859158

Felippe GM, Dale JE (1990). The effects of phosphate supply on growth of plants from the Brasilian Cerrado: experiments with seedlings of the annual weed, Bidens gardneri Baker (Compositeae) and the tree, Qualea grandiflora (Mart.) (Vochysiaceae). Oecologia 82: 81-86. doi: 10.1007/BF00318536

Ferreira RA, Davide AC, Tonetti OAO (2001). Morfologia de sementes e plntulas de pau-terra (Qualea grandiflora Mart. - Vochysiaceae) [Morphology of seeds and seedlings of pau terra (Qualea grandiflora Mart. - Vochysiaceae)]. Revista Brasileira de Sementes 23: 116-122. [in Portuguese] - doi: 10.17801/0101-3122/rbs.v23n1p116122

Ferreira JN, Bustamante M, Garcia-Montiel DC, Caylor KK, Davidson EA (2007). Spatial variation in vegetation structure coupled to plant available water determined by two-dimensional soil resistivity profiling in a Brazilian savanna. Oecologia 153: 417-430. - doi: 10.1007/s00442-0070747-6

Ferri MG (1961). Aspects of the soil-water-plant relationships in conexion with some Brazilian types of vegetation. In: "Tropical Soils and Vegetation: Proceedings of the Abidjan Symposium". Abidjan (Côte d'Ivoire) 20-24 Oct 1959. Commission for Technical Cooperation in Africa South of Sahara, UNESCO, Paris, France, pp. 103-109. [online] URL: http://unesdoc.unesco. org/ark:/48223/pfooo0019446

Fischer EA, Gordo M (1993). Qualea cordata, pollination by the territorial bee Centris tarsata in the "campos rupestres", Brazil. Ciência e Cultura, Journal of the Brazilian Association for the Advancement of Science 45 (2): 144-147.

Gaspi FOG, Foglio MA, Carvalho JE, Moreno RA (2006). Pharmacological activities investigation of crude extracts and fractions from Qualea grandiflora Mart. Journal of Ethnopharmacology 107: 19-24. - doi: 10.1016/j.jep.2006.01.023 Hermann SM, Hook TV, Flowers RW, Brennan LA, Glitzenstein JS, Streng DR, Walker JL, Myers RL (1998). Fire and biodiversity: studies of vegetation and arthropods. Transactions $63^{\text {rd }}$ North American Wildlife and Natural Resources Conference 63: 384-401. [online] URL: http:// www.fs.usda.gov/treesearch/pubs/456 Hiruma-Lima CA, Santos LC, Kushima H, Pellizzon $\mathrm{CH}$, Silveira GG, Vasconcelos PCP, Vilegas W, Souza Brito ARM (2006). Qualea grandiflora, a Brazilian "cerrado" medicinal plant presents an important antiulcer activity. Journal of Ethnopharmacology 104: 207-214. - doi: 10.1016/j.jep. 2005.09.002

Hoffmann W (2000). Post-establishment seedling success in the Brazilian cerrado: a comparison of savanna and forest species. Biotropica 32: 62-69. - doi: 10.1111/j.1744-7429.2000.tboo4 $48 . x$

Hoffmann WA, Franco AC (2003). Comparative growth analysis of tropical forest and savanna 
woody plants using phylogenetically independent contrasts. Journal of Ecology 91: 475-484. - doi: 10.1046/j.1365-2745.2003.00777.x

Hoffmann WA, Lucatelli VMPC, Silva FJ, Azeuedo INC, Marinho MS, Albuquerque AMS, Lopes AO, Moreira SP (2004). Impact of the invasive alien grass Melinis minutiflora at the savannaforest ecotone in the Brazilian Cerrado. Diversity and Distributions 10: 99-103. - doi: 10.1111/ j.1366-9516.2004.00063.x

Jardim AVF, Batalha MA (2009). Dispersal syndromes related to edge distance in cerrado censu stricto fragments of central-western Brazil. Brazilian Archives of Biology and Technology 52: 1167-1177. - doi: 10.1590/S1516-891320 09000500014

Jepson W, Brannstrom C, Filippi A (2010). Access regimes and regional land change in the Brazilian cerrado, 1972-2002. Annals of the American Association of Geographers 100: 87-111. - doi: 10.1080/00045600903378960

Khurana E, Singh JS (2001). Ecology of seed and seedling growth for conservation and restoration of tropical dry forest: a review. Environmental Conservation 28 (1): 39-52. - doi: 10.1017/ So376892901000042

Klein AL (2000). Eugen Warming e o cerrado brasileiro: um século depois [Eugen Warming and the Brazilian cerrado: a century later]. Editora UNESP, Imprensa Oficial do Estado, Sao Pãulo, Brazil, pp. 156. [in Portuguese]

Kutschenko DC (2009). Fenologia e caracterização de frutos e sementes de um cerrado sensu stricto, Jardim Botânico de Brasília, Distrito Federal, Brasil, com ênfase nas espécies com síndrome ornitocórica [Phenology and characterization of fruits and seeds in a cerrado (sensu stricto), Botanical Garden of Brasília, Federal District, Brazil, with emphasis on bird dispersed species]. M.Sc. thesis, Departamento de Botnica, Universidade de Brasília, Brasília, Brazil, pp. 88. [in Portuguese]

Lacerda Resende J (2003). Síndromes de dispersão e fenologia reprodutiva de 50 espécies amplamente distribuídas no Cerrado sentido restrito [Dispersal syndromes and reproductive phenology of 50 species widely distributed in the cerrado (sensu stricto)]. Universidade de Brasília, Instituto de Biologia, Brasília, Brazil, pp. 92. [in Portuguese]

Leck MA, Parker VT, Simpson RL (2008). Seedling ecology and evolution. University Press, Cambridge, UK, pp. 514. [online] URL: http:// books.google.com/books?id=IPSYJWMHanAC

Leite PTP, Filho MT, Morellato LPC (2016). Management of cerrado trees using growth rings. Australian Journal of Basic and Applied Sciences 10 (16): 92-103.

Lenza E, Klink CA (2006). Comportamento fenológico de espécies lenhosas em um cerrado sentido restrito de Brasília, DF [Phenological behavior of woody species in a cerrado (sensu stricto) in Brasília, DF]. Revista Brasileira de Botânica 29: 627-638. [in Portuguese]

Lima-Ribeiro M (2007). Distribuição espacial de espécies arbóreas em fragmentos de Cerrado sentido restrito no planalto central BrasileiroGO [Spatial distribution of woody species in a cerrado (sensu stricto) plateau fragments of central Brazil, Goiás]. Biociências 15: 160-165. [in Portuguese]
Litt A, Stevenson DW (2003). Floral development and morphology of Vochysiaceae. I. The structure of the gynoecium. American Journal of Botany 90: 1533-1547. - doi: 10.3732/ajb.90.11.15 33

Lorenzi H (2002). Árvores brasileiras: manual de identificação e cultivo de plantas arbóreas nativas do Brasil. [Brazilian trees: identification manual and cultivation of native arboreal plants of Brazil] Editora Plantarum Nova Odessa, São Paulo, Brazil, pp. 368. [in Portuguese] Luz GR, Menino GOG, Mota SG, Nunes FRY (2008). Síndromes de dispersão de espécies arbustivo-arbóreas em diferentes fitofisionomias no norte de Minas Gerais [Dispersal syndromes of shrub-tree species in different vegetation types in north of Minas Gerais]. In: “IX Simpósio Nacional Cerrado e II Simpósio Internacional Savanas Tropicais". Embrapa, Planaltina, Brazil, pp. 1132. [in Portuguese].

Mantovani W, Martins FR (1993). Florística do cerrado na reserva biológica De Moji Guaçu, Sp [Flora composition of the Cerrado in the Biological Reserve of Moji Guaçu, Sp]. Acta Botanica Brasilica 7(1): 33-60. [in Portuguese] - doi: 10.1590/S0102-33061993000100003

Martinez-Ramos M, Pingarroni A, RodríguezVelázquez J, Toledo-Chelala L, Isela ZermeñoHernández, Bongers F (2016). Natural forest regeneration and ecological restoration in human-modified tropical landscapes. Biotropica 48(6): 745-757. - doi: 10.1111/btp.12382

Medeiros MB, Miranda HS (2008). Post-fire resprouting and mortality in cerrado woody plant species over a three-year period. Edinburgh Journal of Botany 65: 53-68. - doi: 10.1017/So 960428608004708

Miranda AC, Miranda HS, Oliveira Dias IF, Souza Dias BF (1993). Soil and air temperatures during prescribed cerrado fires in central Brazil. Journal of Tropical Ecology 9: 313-320. - doi: 10.1017/ So266467400007367

Moreira GL, De Sousa JC, Dos Santos ML (2009). O serviço de polinizadores e a eficácia reprodutiva das plantas do cerrado de Anápolis [Service of pollinators and the reproduction efficacy of plants of cerrado of Anápolis]. State University of Goiás, Brazil, pp. 1-6. [in Portuguese]

Moreira AG, Klink CA (2000). Biomass allocation and growth of tree seedlings from two contrasting Brazilian savannas. Ecotropicos 13: 4351.

Myers N (2000). Biodiversity hotspots for conservation priorities. Nature 403: 853-858. - doi: $10.1038 / 35002501$

Negrelle RRB (2011). Qualea Aubl. from Paraná State, Brazil. Acta Scientiarum. Biological Sciences 33: 347-355. - doi: 10.4025/actascibiolsci. v33iз.3671

Norden $\mathrm{N}$, Chave J, Belbenoit $P$, Caubère $A$, Chtelet P, Forget PM, RiéraB, Viers J, Thébaud $C$ (2009). Interspecific variation in seedling responses to seed limitation and habitat conditions for 14 neotropical woody species. Journal of Ecology 97: 186-197. - doi: 10.1111/j.1365-2745. 2008.01444.x

Nyland RD (2002). Silviculture: concepts and applications ( $2^{\text {nd }}$ edn). McGraw-Hill, Boston, MS, USA, pp. 682.

Oliveira PEAM, Moreira AG (1992). Anemocoria em espécies de Cerrado e mata de galeria de Brasília, DF [Anemochory in cerrado and gallery forests species of Brasília, DF]. Revista Brasileira de Botânica 15: 163-174. [in Portuguese]

Oliveira PE, Gibbs PE, Barbosa AA (2004). Moth pollination of woody species in the cerrados of Central Brazil: a case of so much owed to so few? Plant Systematics and Evolution 245: 4154. - doi: 10.1007/s00606-003-0120-0

Oliveira PS, Marquis RJ (2002). The cerrados of Brazil: ecology and natural history of a neotropical savanna. Columbia University Press, New York, USA, pp. 398.

Palermo AC, Miranda HS (2012). Effect of fire on the fruit production of Qualea parviflora Mart. (Vochysiaceae) in the cerrado. Revista Árvore, Viçosa-MG 36: 685-693. - doi: 10.1590/S010067622012000400010

Paulilo MTS (1991). Qualea grandiflora Mart.: crescimento inicial e crescimento foliar em árvores [Qualea grandiflora Mart.: initial growth and leaf growth in trees]. PhD thesis, Universidade de Campinas, Brazil, pp. 199. [in Portuguese]

Paulilo MTS, Felippe GM, Dale JE (1998). Root/ shoot partitioning and water relations in Qualea grandiflora (Vochysiaceae) seedlings under water stress. Revista de Biologia Tropical 46: 41-44.

Pellizzaro KF, Cordeiro AOO, Alves M, Motta CP, Rezende GM, Silva RRP, Ribeiro JF, Sampaio AB, Vieira DLM, Schmidt IB (2017). "Cerrado" restoration by direct seeding: field establishment and initial growth of 75 trees, shrubs and grass species. Brazilian Journal of Botany 40 (3): 681-693. - doi: 10.1007/s40415-017-0371-6

Pirani FR, Sanchez M, Pedroni F (2009). Fenologia de uma comunidade arbórea em Cerrado sentido restrito, Barra do Garças, MT, Brasil [Phenology of a woody community of a cerrado (sensu stricto), Barra do Garças, Mato Grosso, Brazil]. Acta Botanica Brasilica 23: 1096 1109. [in Portuguese] - doi: 10.1590/S0102-33062 009000400019

Pivello VR, Vieira MV, Grombone-Guaratinic MT, Matos DMS (2018). Thinking about super-dominant populations of native species - Examples from Brazil. Perspectives in Ecology and Conservation 16 (2): 74-82. - doi: 10.1016/j.pecon.20 18.04.001

Potascheff $C M$, Oddou-Muratorio $S$, Klein EK, Figueira A, Bressan EA, Oliveira PE, Lander TA, Sebbenn AM (2019). Stepping stones or stone dead? Fecundity, pollen dispersal and mating patterns of roadside Qualea grandiflora Mart. trees. Conservation Genetics 20: 1355-1367. doi: 10.1007/s10592-019-01217-w

Protásio TP, Neto RMG, Santana JDP, Júnior JBG, Trugilho PF (2014). Canonical correlation analysis of the characteristics of charcoal from Qualea parviflora Mart. Cerne, Lavras 20 (1): 8188. - doi: 10.1590/S0104-77602014000100011

Ramos-Neto MB, Pivello VR (2000). Lightning fires in a Brazilian savanna national park: rethinking management strategies. Environmental Management 26: 675-684. - doi: 10.1007/soo 2670010124

Ragusa-Netto J, Santos AA (2015). Seed rain generated by bats under Cerrado's pasture remnant trees in a Neotropical savanna. Brazilian Journal of Biology 75 (suppl. 1): S25-S34. - doi: 
10.1590/1519-6984.22813

Ratter JA, Bridgewater S, Ribeiro JF (2003). Analysis of the floristic composition of the Brazilian Cerrado vegetation III: comparison of the woody vegetation of 376 areas. Edinburgh Journal of Botany 60: 57-109. - doi: 10.1017/So 960428603000064

Rawitscher F (1948). The water economy of the vegetation of the "Campos Cerrados" in southern Brazil. Journal of Ecology 36: 237-268. - doi: 10.2307/2256669

Reich PB, Borchert R (1984). Water stress and tree phenology in a tropical dry forest in the lowlands of Costa Rica. Journal of Ecology 72: 61-74. - doi: 10.2307/2260006

Ribeiro LC, Pedrosa M, Borghetti F (2013). Heat shock effects on seed germination of five Brazilian savanna species. Plant Biology 15: 152157. - doi: 10.1111/j.1438-8677.2012.00604.x

Ribeiro LC, Borghetti F (2014). Comparative effects of desiccation, heat shock and high temperatures on seed germination of savanna and forest tree species. Austral Ecology 39: 267-278. - doi: 10.1111/aec.12076

Ritter LMO, Bajay MM, Monteiro M, Souza RGVC, Moreno MA, Kageyama PY (2012). Development of microsatellite makers for Qualea grandiflora (Vochysiaceae), a typical species of the Brazilian Cerrado. American Journal of Botany 99 (3): e97-e98. - doi: 10.3732/ajb.1100405

Rizzini C (1965). Experimental studies on seedling development of cerrado woody plants. Annals of the Missouri Botanical Garden 52: 410426. - doi: $10.2307 / 2394803$

Roitman I, Felfili JM, Rezende AV (2008). Tree dynamics of a fire-protected cerrado sensu stricto surrounded by forest plantations, over a 13-year period (1991-2004) in Bahia, Brazil. Plant Ecology 197: 255-267. - doi: 10.1007/s11258-0079375-9

Rosseto V, Araújo JS, Sfair JC, Latini AO (2005). Avaliação da distribuição de espécies arbóreas em um fragmento de cerrado do município de Itirapina. [Analysis of the distribution of woody species in a cerrado fragment of Itirapina municipality]. Department of Botany, State University of Campinas, São Paulo, Brazil, pp. 13. [in Portuguese]
Ruggiero PGC, Batalha MA, Pivello VP, Meirelles ST (2002). Soil-vegetation relationships in cerrado (Brazilian savanna) and semideciduous forest, Southeastern Brazil. Plant Ecology 160: 1-16. - doi: 10.1023/A:1015819219386

Salazar A (2010). Seed dynamics and seedling establishment of woody species in the tropical savannas of central Brazil (Cerrado). PhD thesis, Department of Biology, University of Miami, FL, USA, pp. 180.

Salazar A, Goldstein G, Franco AC, Miralles-Wilhelm F (2012). Seed limitation of woody plants in neotropical savannas. Plant Ecology 213: 273287. - doi: 10.1007/s11258-011-9973-4

Santos FP, De Melo Ferreira W (2012). Estudo fenológico de Davilla elliptica St. Hill. e Qualea grandiflora Mart. em uma área de Cerrado sentido restrito em Porto Nacional, Tocantins [Study of phenology of Davilla elliptica St. Hill. and Qualea grandiflora Mart. in a cerrado (sensu stricto) area in Porto Nacional, Tocantins]. Revista Interface (Porto Nacional) 5: 3-14. [in Portuguese]

Silberbauer-Gottsberger I (2001). A hectare of cerrado. II. Flowering and fruiting of thickstemmed woody species. Phyton 41: 129-158.

Silva RRP, Vieira DLM (2017). Direct seeding of 16 Brazilian savanna trees: responses to seed burial, mulching and an invasive grass. Applied Vegetation Science 20 (3): 410-421. - doi: 10.1111/ avsc. 12305

Silvério DV, Lenza E (2010). Phenology of woody species in a typical cerrado in the Bacaba Municipal Park, Nova Xavantina, Mato Grosso, Brazil. Biota Neotropica 10 (3): 205-216. - doi: 10.1590/S1676-06032010000300024

Simon MF, Grether R, De Queiroz LP, Skema C, Pennington RT, Hugheset CE (2009). Recent assembly of the cerrado, a neotropical plant diversity hotspot, by in situ evolution of adaptations to fire. Proceedings of the National Academy of Sciences USA 106: 20359-20364. - doi: 10.1073/pnas.0903410106

Siqueira MFD, Peterson AT (2003). Global climate change consequences for cerrado tree species. Biota Neotropica 3: 1-14. - doi: 10.1590/ S1676-06032003000200005

Soares JJ, Souza MHAO, Lima MIS (2006).
Twenty years of post-fire plant succession in a “cerrado", São Carlos, SP. Brazilian Journal of Biology 66 (2b): 587-602.

Stafleu FA (1953). A monograph of the Vochysiaceae. Part III. Qualea. Acta Botanica Neerlandica 2: 144-217. - doi: 10.1111/j.1438-8677.1953. tbo0271.x

Van Schaik CP, Terborgh JW, Wright SJ (1993). The phenology of tropical forests: adaptive significance and consequences for primary consumers. Annual Review of Ecology and Systematics 24: 353-377. - doi: 10.1146/annurev.es.24.11 0193.002033

Vieira DLM, De Lima VV, Sevilha AC, Scariot A (2008). Consequences of dry-season seed dispersal on seedling establishment of dry forest trees: should we store seeds until the rains? Forest Ecology and Management 256: 471-481. doi: 10.1016/j.foreco.2008.04.052

Waldrop TA, White DL, Jones SM (1992). Fire regimes for pine-grassland communities in the southeastern United States. Forest Ecology and Management 47: 195-210. - doi: 10.1016/03 78-1127(92)90274-D

Walters M, Midgley JJ, Somers MJ (2004). Effects of fire and fire intensity on the germination and establishment of Acacia karroo, Acacia nilotica, Acacia luederitzii and Dichrostachys cinerea in the field. BMC Ecology 4 (1): 3. - doi: 10.1186/1472-6785-4-3

Zaidan LBP, Carreira RC (2008). Seed germination in cerrado species. Brazilian Journal of Plant Physiology 20: 167-181. - doi: 10.1590/S1 677-04202008000300002

\section{Supplementary Material}

Tab. S1 - Overview of the English, Portuguese and Spanish keywords used in the search for relevant literature.

Fig. S1 - Distribution of studies in South America documented in relevant publications.

Link: DaPonte_2684@supplo01.pdf 